

\title{
PEMBELAJARAN FISIKA BERBASIS WEB ENHANCED COURSE: MENGEMBANGKAN WEB-LOGS PEMBELAJARAN FISIKA DASAR I
}

\author{
Ardian Asyhari, Rahma Diani \\ Fakultas Tarbiyah dan Keguruan UIN Raden Intan Lampung \\ ardianasyhari@radenintan.ac.id, rahmadiani@radenintan.ac.id
}

\begin{abstract}
Abstrak
Penelitian ini bertujuan untuk mengembangkan Web-blogs dengan metode R\&D prosedur 4D (define, design, develop, disseminate) yang dapat mendukung Web Enhanced Course (WEC) agar menunjang pembelajaran Fisika Dasar 1 materi Gerak Dua Dimensi pada mahasiswa Program Studi Pendidikan Fisika UIN Raden Intan Lampung, dan mengetahui kriteria penilaian melalui validasi produk dari ahli desain instruksional, ahli media pembelajaran, dan ahli web designer. Serta mengetahui tanggapan mahasiswa terkait kemenarikan produk dan kemudahan penggunaan dari produk yang dikembangkan. Spesifikasi pada WEC yang dikembangkan menekankan pada web yang memungkinkan terjadinya komunikasi interaktif antara dosen dan mahasiswa, baik secara individu maupun kelompok, serta dapat menjadi alternatif belajar secara online. Setelah divalidasi oleh ahli desain instruksional, ahli media pembelajaran, dan ahli website designer, didapatkan nilai dengan kriteria "sangat baik" dan memperoleh nilai dengan kriteria "sangat baik" setelah dilakukan uji coba terbatas $(\mathrm{N}=15)$ dan uji coba diperluas $(\mathrm{N}=90)$ dalam hal kemenarikan desain dan kemudahan penggunaan produk awal dan produk akhir dari WEC yang dikembangkan.
\end{abstract}

Kata kunci: RED, web enhanced course, fisika dasar I

\section{PHYSICS LEARNING BASED ON WEB ENHANCED COURSE: DEVELOPING WEB- LOGS TO SUPPORT PHYSICS I COURSE}

\author{
Ardian Asyhari, Rahma Diani \\ Faculty of Teacher Training and Education UIN Raden Intan Lampung \\ ardianasyhari@radenintan.ac.id, rahmadiani@radenintan.ac.id
}

\section{Abstract}

This research aims to (1) develop a Web-blogs by the method of $R \mathcal{E} D$ procedures $4 D$ (define, design, develop, disseminate) that can support Web Enhanced Course (WEC) to help to learn Physics 1 material Motion Two-Dimensional student department of physics education UIN Raden Intan Lampung. (2) Know the assessment criteria through product validation from instructional design experts, learning media experts, and web designers expert. Moreover, (3) knowing the students' responses related to the attractiveness of the product and the ease of use of the developed product. Specifications on the WEC developed an emphasis on the web that enables interactive communication between faculty and students, either individually or in groups, and can be an alternative to online learning. After being validated by an instructional design expert, an instructional media expert, and a website designer. A score of "excellent" criteria was obtained and scored with "excellent" criteria after a limited trial $(N=15)$ and an expanded trial $(N=90)$ regarding design attractiveness and ease of use of the initial product and end product of the developed WEC.

Keywords: $R$ \& D, Web Enhanced Course, Physics I 


\section{Pendahuluan}

Membuat sebuah keputusan untuk terus berinovasi dalam pembelajaran merupakan pilihan yang harus dipilih oleh semua pendidik. Teknologi Informasi dan Komunikasi (TIK) yang telah sangat pesat berkembang, menyebabkan dunia pendidikan juga harus memiliki kepentingan yang besar agar dapat sejalan dengan kemajuan tersebut. Selain itu, hasil penelitian pun menunjukkan bahwa semakin canggihnya perkembangan teknologi, akan pula menggeser kebiasaan belajar siswa (Woo et al., 2008; Ke \& Alicia, 2013).

Dalam satu dekade terakhir, banyak ditemukan penelitian yang membicarakan tentang penggunaan media pembelajaran berbasis online, khususnya pembelajaran berbasis web. Terkoneksinya hampir semua orang di internet dapat dimaksimalkan dalam kegiatan pembelajaran. Apabila kegiatan pembelajaran berbasis web telah dan akan semakin meluas, penting bagi pendidik untuk menetapkan kegunaan dari hal tersebut untuk mencapai tujuan pembelajaran (Sheard \& Markham, 2005).

Web telah lama menjadi sumber untuk mengajar dan pembelajaran pada berbagai disiplin ilmu (Liu \& Johnson, 2004). Penggunaan Web-blog sebagai media pembelajaran dapat diartikan juga sebagai pe-manfaatan HTML (Hyper Text MarkUP Language) dalam pembelajaran. Candiasa (2004) menjelaskan bahwa struktur pohon dalam tatacara pemanggilan informasi dari satu bingkai ke bingkai yang lain pada hyper text sangat mendukung terciptanya jaringan materi pembelajaran.

Salah satu bentuk pemanfaatan dari penggunaan web dalam kegiatan pembelajaran adalah web enhanced course (WEC). Media Web sangat baik digunakan sebagai media pembelajaran fisika. Media ini dapat menjadi alternatif karena diyakini dapat menarik perhatian siswa terhadap pelajaran fisika (Irwandani, 2014). (Sa'ud, 2009) menjelaskan bahwa WEC merupakan pemanfaatan internet untuk pendidikan, untuk menunjang peningkatan kualitas bel- ajar mengajar di kelas. Bentuk ini juga dikenal dengan nama web lite course, karena kegiatan pembelajaran utama adalah tatap muka di kelas. Fungsi internet adalah untuk memberikan pengayaan dan komunikasi antara mahasiswa dengan dosen, sesama mahasiswa, atau mahasiswa dengan narasumber lain. Oleh karena itu, peran dosen dalam hal ini dituntut untuk menguasai teknik mencari informasi di internet, membimbing mahasiswa mencari dan menemukan situs-situs yang relevan dengan bahan pembelajaran, menyajikan materi melalui web yang menarik dan diminati, melayani bimbingan dan komunikasi melalui internet, serta kecakapan lain yang diperlukan (Alfath, Ellianawati, \& Sukisno, 2013).

Sebelum memutuskan untuk menggunakan WEC, Zirkle (2003) menjelaskan bahwa ketersediaan software dan hardware (komputer atau laptop, modem, web brows$e r$, internet penyedia layanan internet, dsb.) adalah hal penting yang harus diperhatikan. Sejalan dengan rekomendasi tersebut, potensi berkembangnya kegiatan pembelajaran berbasis WEC pada Program Studi Pendidikan Fisika UIN Raden Intan Lampung muncul sejak meningkatnya layanan wifi hotspot. Sebelumnya, antena berkecepatan 20 Mbps hanya terpusat di fakultas dan dipakai secara bersama oleh semua program studi, namun sejak tahun 2015, kecepatan layanan menjadi $20 \mathrm{Mbps}$ hanya untuk Program Studi Pendidikan Fisika (PSPF) saja. Selain itu, berdasarkan hasil observasi, hampir semua mahasiswa PSPF telah menggunakan Smartphone berbasis Android $^{\mathrm{TM}}$ dan memiliki laptop. Penjabaran tersebut menarik peneliti untuk memfokuskan diskusi pada pengembangan desain web-logs (Blogs) yang dapat mendukung web enhanced course dan memungkinkan terjadinya komunikasi interaktif antara dosen dan mahasiswa, baik secara individu maupun kelompok sebagai sebuah alternatif belajar secara online dan mengetahui kriteria penilaian produk dari ahli desain instruksional, ahli media pembelajaran, dan ahli web designer. Serta mengetahui tang- 
gapan mahasiswa terkait kemenarikan produk dan kemudahan penggunaan dari produk yang dikembangkan.

\section{Metode Penelitian}

Penelitian ini menggunakan metode Research and Development yang diadaptasi dari model Four-D oleh Thiagarajan, Semmel, \& Semmel (1974) dengan tahapan Define (pendefinisian), Design (perancangan), Develop (pengembangan), dan Disseminate (penyebaran).

Prosedur pengembangan web enhanced course hasil adaptasi model four- $D$ untuk tiap langkah dapat dilihat pada Gambar 1. Penelitian ini dilakukan di Program Studi Pendidikan Fisika Universitas Islam Negeri Raden Intan Lampung selama Semester Ganjil 2016/2017 dengan mengambil mahasiswa kelas Fisika Dasar I sebanyak 15 orang sebagai subjek penelitian pada uji coba I (terbatas) yang dipilih dengan metode nonrandom sampling tipe convenience sampling untuk mengetahui tanggapan mereka terkait kemenarikan desain dan kemudahan penggunaan produk awal WEC, dan sebanyak 90 orang mahasiswa (seluruh mahasiswa yang mengikuti kelas Fisika Dasar I) sebagai subjek uji coba II (diperluas) untuk mengetahui tanggapan mereka terkait kemenarikan desain dan kemudahan penggunaan produk akhir WEC yang dikembangkan. Pengumpulan data dilakukan dengan metode wawancara, observasi, dan validasi. Instrumen yang digunakan dalam penelitian ini, yaitu instrumen observasi dan wawancara pada langkah define. Pada tahap develop digunakan instrumen validasi ahli oleh ahli desain instruksional, ahli Website Designer, dan ahli media pembelajaran yang diadaptasi dari Keing \& McNaught (2005), serta instrumen untuk mengetahui tanggapan kemenarikan dan kemudahan penggunaan dari produk yang dikembangkan pada tahap Uji Coba I dan II yang disediakan secara online.

Data dari instrumen validasi untuk ahli desain instruksional berupa data ordinal pada aspek penilaian manajemen pem- belajaran sebanyak 3 item pertanyaan dan penilaian dukungan untuk pembelajaran kolaboratif sebanyak 4 item pertanyaan. Untuk ahli media pembelajaran berupa data ordinal pada aspek penilaian desain antarmuka sebanyak 5 item pertanyaan, dan data ketersediaan informasi pada WEC sebanyak 9 item pertanyaan. Sedangkan lembar validasi untuk ahli website designer berupa data ordinal pada aspek penilaian ketersediaan informasi WEC sebanyak 9 item pertanyaan, kemudahan penggunaan sebanyak 5 item pertanyaan, aspek penilaian manajemen WEC sebanyak 3 pertanyaan, desain antarmuka sebanyak 5 item pertanyaan, dan daya tarik sebanyak 4 item pertanyaan. Terakhir adalah data berupa tanggapan yang diisi oleh 15 orang mahasiswa pada uji coba terbatas dan 90 orang mahasiswa pada uji coba diperluas. Kemudian nilai produk ditentukan dengan mengubahnya menjadi persentase dengan skala 0 - 100 \% (Asyhari, Irwandani, \& Saputra, 2016; Asyhari, Sunarno, \& Sarwanto, 2014; Asyhari \& Silvia, 2016; Asyhari, Wati, \& Syahidah, 2016; Asyhari, Windarti, \& Wati, 2016).

Skor dari setiap pernyataan untuk seluruh validator dirata-ratakan dan dinyatakan dalam bentuk persentase capaian dengan menggunakan persamaan:

$$
\% S S=\frac{\overline{S S}}{S_{m}} x 100 \%
$$

Keterangan:

SS $=$ Skor rata-rata

$\mathrm{S}_{\mathrm{m}}=$ Skor maksimal

Untuk menginterpretasikan persentase hasil validasi ahli, digunakan kriteria yang terdapat pada Tabel 1 .

Tabel 1. Skala Interpretasi Kriteria

\begin{tabular}{cc}
\hline Interval & Kriteria \\
\hline $0 \%-20 \%$ & Sangat Kurang Baik \\
$21 \%-40 \%$ & Kurang Baik \\
$41 \%-60 \%$ & Cukup Baik \\
$61 \%-80 \%$ & Baik \\
$81 \%-100 \%$ & Sangat Baik \\
\hline
\end{tabular}






Gambar 1. Prosedur Pengembangan WEC dengan Model Four-D

(Thiagarajan, Semmel, \& Semmel, 1974)

Pembahasan data hasil validasi dan hasil uji statistik dilakukan dengan metode pembuktian (evidence), yaitu: (1) Bukti yang berdasarkan pada hubungan antara skor pada prediktor dan variabel lainnya; (2) Bukti Berdasarkan isi; (3) bukti berdasarkan proses respons; dan (4) Bukti berdasarkan pada konsekuensi dari keputusan pribadi. Kemudian bukti tersebut diinterpretasikan sesuai dengan teori-teori yang mendukung (Zumbo \& Chan, 2014).

\section{Hasil Dan Pembahasan}

Hasil dan pembahasan dari setiap tahap pengembangan model Four-D, akan dibahas tiap langkah sebagai berikut.

\section{Define (Perencanaan)}

\section{Analisis Awal-Akhir}

Potensi permasalahan yang mendasar dalam pengembangan WEC yaitu ketersediaan waktu dalam mendesain dan memelihara web; kemampuan dalam mempelajari dan memahami bahasa HTML; serta ketersediaan software dan hardware (Keing \& McNaught, 2005).

Untuk mengatasi hal tersebut, peneliti menggunakan waktu senggangnya di ruangan kerja untuk fokus pada pengembangan web lebih lanjut. Pengetahuan tentang kode HTML yang menjadi salah satu masalah yang dihadapi peneliti, dapat dengan mudah dipelajari dengan bantuan 
website http://www.w3schools.com/, sedangkan pada potensi permasalahan hardware dan software dalam mengembangkan WEC dapat teratasi seperti yang telah dibahas pada bagian pendahuluan.

\section{Analisis Pembelajar}

Karakteristik mahasiswa Program Studi Pendidikan Fisika UIN Raden Intan Lampung berdasarkan hasil wawancara dan observasi yang telah dilakukan, didapatkan bahwa frekuensi mahasiswa dalam menjelajah internet cukup tinggi, mereka telah menyadari pentingnya teknologi untuk pembelajaran, dan lebih sering mencari materi pembelajaran / perkuliahan melalui internet dibanding buku.

\section{Analisis Tugas}

Berdasarkan kajian kepustakaan, diperoleh bahwa standar pada WEC yang akan dikembangkan akan: (1) berisi informasi yang lengkap tentang web tersebut, terutama tentang perkuliahan Fisika Dasar I; (2) mendukung manajemen perkuliahan Fisika Dasar 1; dan (3) Mendukung kolaborasi antara pendidik dan peserta didik.

\section{Analisis Konsep}

Analisis konsep menghasilkan ketentuan tentang materi perkuliahan yang disampaikan dan cara untuk menyampaikan materi tersebut di web. Materi perkuliahan yang akan disampaikan yaitu materi tentang gerak satu dimensi dan gerak dua dimensi yang disusun berdasarkan hasil kajian Buku Fisika Dasar untuk tingkat Universitas.

\section{Spesifikasi Tujuan Pengembangan}

Spesifikasi tujuan pengembangan dilakukan untuk menentukan indikator dari ketercapaian standar web yang dikembangkan. Indikator ketercapaian: (1) ketersediaan informasi pada web perkuliahan Fisika Dasar 1 yang dikembangkan yaitu akan berisi judul pembelajaran dan deskripsinya, isi dari materi berupa catatan konsep yang fundamental, berisikan capaian pembelajaran, aktivitas pembelajaran, keterangan penilaian, umpan balik untuk evaluasi pembelajaran, jadwal pembelajaran, keterangan kontak, dan berisikan pengumuman hal-hal yang terkait perkuliahan. Ketercapaian indikator; (2) web yang mendukung manajemen perkuliahan Fisika Dasar 1 akan dapat ditentukan apabila web tersebut dapat digunakan untuk berbagi bahan pengajaran dan pembelajaran, mengumpulkan pekerjaan rumah secara online, menyiapkan latihan pembelajaran secara otomatis dinilai. Sedangkan Indikator ketercapaian aspek (3) mendukung pembelajaran kolaboratif dapat ditentukan apabila web menyiapkan forum untuk meningkatkan interaksi dosen dan mahasiswa, menyediakan ruang kerja virtual untuk kerja kelompok (file sharing, forum diskusi, dll.), menyediakan lingkungan virtual untuk pertukaran antar-institusi, dan mendorong peer-review di kalangan mahasiswa.

\section{Design (Perancangan)}

\section{Penyusunan WEC}

Pada tahapan penyusunan WEC, ditentukanlah desain antarmuka dan tata letak dari WEC yang dikembangkan untuk bagian perkuliahan. sehingga dapat mengakomodasi indikator ketercapaian tujuan pengembangan indikator (1). Hasil penyusunan antar muka web untuk bagian perkuliahan yang diadaptasi dari laman https://ocw.mit.edu/courses/physics ditunjukkan pada Gambar 2.

Bagian antarmuka tersebut berisikan identitas mata kuliah, silabus, kalender perkuliahan, catatan kuliah, penugasan, dan bahan bacaan yang direkomendasikan. Laman tersebut dapat diakses pada http://www.ardianasyhari.com/p/physic s-i-home.html dan bagian menu WEC dibahas lebih lanjut pada bagian desain awal.

Untuk mengakomodasi indikator (2) dan (3), maka ditentukanlah bahwa web tersebut juga menyediakan layanan diskusi yang dapat menjadi tempat untuk berbagi ide, pekerjaan, dan saling berinteraksi (Gambar 3). Forum diskusi tersebut merupakan layanan yang disediakan secara gratis oleh http:/ / www.nabble.com/ 
PHYSICS I - HOME

\begin{tabular}{|l|l|l|l|l|} 
Syllabus & Calendar & Lecture Notes & Assignments & Readings \\
\hline
\end{tabular}

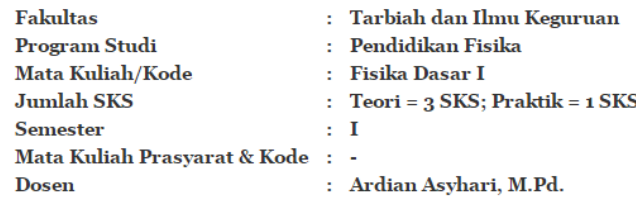

Gambar 2. Antarmuka laman perkuliahan Fisika Dasar 1 (Course)

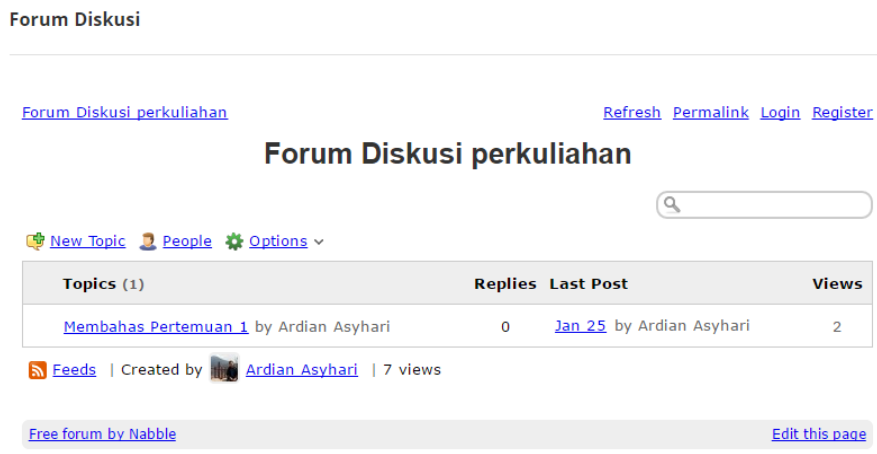

Gambar 3. Antarmuka laman forum diskusi (http://www.ardianasyhari.com/p/forum-diskusi.html)

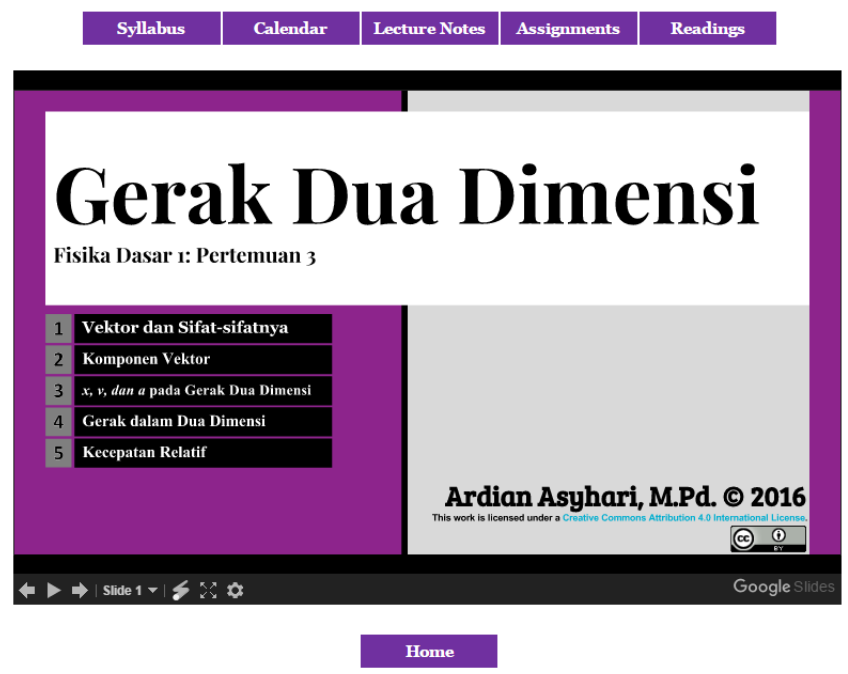

Gambar 4. Google Slide untuk materi Gerak Dua Dimensi (http://www.ardianasyhari.com/p/fisdas1p3.html)

\section{Pemilihan Media}

Media yang dipilih untuk di-embed pada web sehingga dapat mendukung WEC adalah layanan Google Slide yang dapat diakses secara bersamaan baik di smartphone maupun laptop siswa (Gambar 4).

\section{Pemilihan Format}

Format Web yang menjadi pilihan peneliti adalah layanan yang disediakan oleh http://www.blogger.com/ (layanan google) dengan domain berbayar (custom domain) dan template yang disediakan

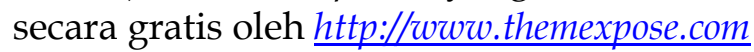




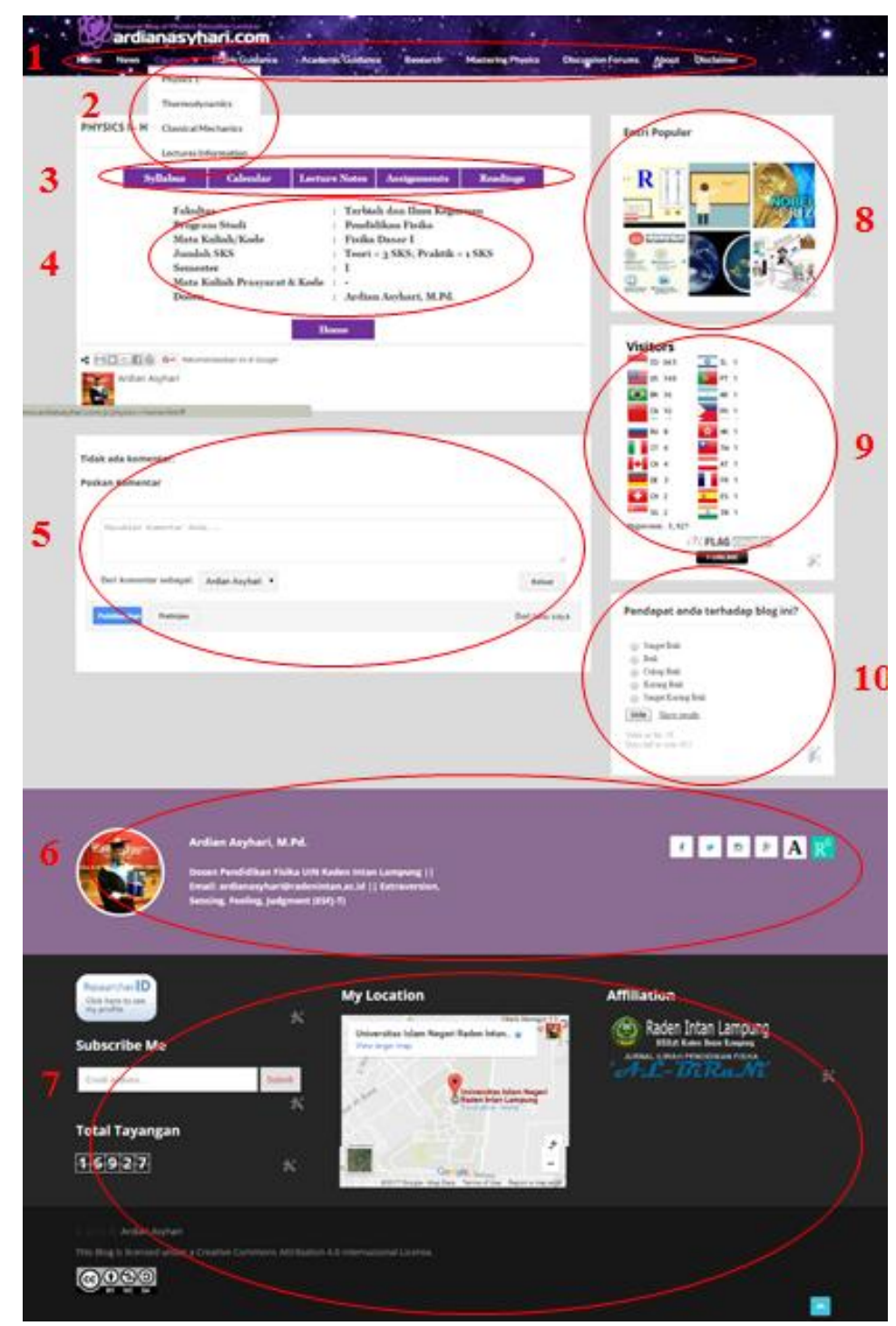

Gambar 5. Desain Awal Laman WEC http://www.ardianasyhari.com/p/physics-i-home.html

(1) Header, (2) Submenu, (3) Menu WEC, (4) Main Post, (5) Kolom Komentar, (6) Owner Profile, (7) Keterangan Lain, (8) Entri Populer, (9) Visitor Counter, dan (10) Online Survei

\section{Desain Awal}

Desain awal WEC dikembangkan dengan mengacu pada desain web pribadi yang dapat dimodifikasi secara bebas sehingga dapat digunakan untuk membantu pembelajaran. Bentuk lengkap dari desain awal WEC yang dikembangkan dapat diakses pada laman http://www.ardianasyhari.com.

Bagian-bagian yang terdapat pada WEC adalah Header, Main Menu, Submenu, Menu WEC, Main Post, kolom komentar, dan owner profile, dan keterangan lainnya.
Sebagian besar pengoperasian WEC terdapat pada bagian submenu (Gambar 5).

Pada bagian desain awal menu WEC (Gambar 6) terdapat menu Home Menu WEC, Syllabus, Calendar, Lecture Notes, Assignments, Readings. Pada bagian Home Menu pada WEC yang dikembangkan (Gambar 2) pada tahap awal terdapat keterangan tentang Identitas mata kuliah (course). Pada bagian Syllabus (Gambar 6) berisi deskripsi mata kuliah, standar kompetensi mata kuliah, referensi/sumber bahan, dan penilaian. 
PHYSICS I - SYLLABUS

I. Deskripsi Mata Kuliah

Mata kuliah ini merupakan satu rangkaian dengan mata kuliah Fisika Dasar II yang akan disajikan pada semester genap. Dengan mata kuliah ini diharapkan dikuasai kompetensi-kompetensi yang berkaitan dengan besaran dan satuan, konsep kinematika dan dinamika, konsep energi dan kekekalan energi, usaha, daya, termodinamika.

II. Standar Kompetensi Mata Kuliah

Mahasiswa mampu menerapkan prinsip dan konsep dasar mekanika dan termodinamika untuk memecahkan masalah yang berkaitan dengan fisika dalam kehidupan sehari-hari.

III. Referensi/ Sumber Bahan

A. Wajib

1. Serway, Raymond A dan Vuille, Chris. (2012). College Physics 9th Edition. Boston: Brooks/Cole.

A. Lampiran

2. Abdullah, Mikrajuddin. (2016). Fisika Dasar I. Bandung: ITB.

IV. Penilaian

A. Memenuhi syarat kehadiran

Jika persentase kehadiran mahasiswa kurang dari $80 \%$ maka nilai akhir tidak diberikan dan mahasiswa dinyatakan tidak lulus.

B. Tugas Mandiri

Tugas mandiri diberikan kepada mahasiswa adalah untuk mendalami bahan kuliah yang telah diberikan. Jumlah tugas mandiri 10 buah dipilih pada bahan yang dianggap penting. Bobot untuk Tugas Mandiri adalah sebesar 20\%. C. Ujian Tengah Semester

Bahan ujian tengah semester adalah bahan yang telah diberikan. Jumlah soal dalam ujian tengah semester adalah 10 buah. Bobot ujian tengah semester adalah $30 \%$.

D. Ujian Akhir Semester

Bahan ujian akhir semester adalah seluruh bahan yang telah diberikan. Jumlah soal dalam ujian akhir semester adalah 10 buah. Komposisi soal terdiri dari 4 soal mudah, 3 soal sedang dan 3 soal sulit. Bobot ujian akhir semester adalah $50 \%$.

\begin{tabular}{|c|l|c|}
\hline No. & Komponen & Bobot (\%) \\
\hline A & Tugas & $20 \%$ \\
\hline B & Ujian Tengah Semester & $30 \%$ \\
\hline C & Ujian Akhir Semester & $50 \%$ \\
\hline \multicolumn{2}{|c|}{ Jumlah } & $100 \%$ \\
\hline
\end{tabular}

Home

Gambar 6. Isi dari bagian Syllabus (Belum Menggunakan KKNI)

PHYSICS I- CALENDAR

\begin{tabular}{|c|c|c|c|c|}
\hline $\begin{array}{c}\text { Minggu } \\
\text { ke- }\end{array}$ & Kompetensi Dasar & Materi Pokok & Sub Materi & $\begin{array}{l}\text { Strategi } \\
\text { Perkuliah } \\
\text { an }\end{array}$ \\
\hline 1 & $\begin{array}{l}\text { Mahasiswa mampu } \\
\text { menjelaskan konsep } \\
\text { dan penerapan } \\
\text { pengukuran, besaran, } \\
\text { dan satuan dalam } \\
\text { fisika. }\end{array}$ & $\begin{array}{l}\text { Pengukuran, } \\
\text { Besaran, dan } \\
\text { Satuan dalam } \\
\text { Fisika. }\end{array}$ & $\begin{array}{l}\text { 1. Standar panjang, } \\
\text { massa dan waktu } \\
\text { 2. Analisis dimensi; } \\
\text { 3. Ketidakpastian } \\
\text { dalam pengukuran } \\
\text { dan } \\
\text { 4. Konversi satuan; } \\
\text { dan } \\
\text { 5. Sistem koordinat. } \\
\text { 6. Trigonometri } \\
\text { 7. Strategi Pemecahan } \\
\text { masalah }\end{array}$ & $\begin{array}{l}\text { 1. Diskusi } \\
\text { 2. Tanya } \\
\text { jawab, } \\
\text { 3. } \\
\text { Pemeca } \\
\text { han soal } \\
\text { kontekst } \\
\text { ual } \\
\text { 4. Tugas. }\end{array}$ \\
\hline 2 & $\begin{array}{l}\text { Mahasiswa mampu } \\
\text { menjelaskan konsep } \\
\text { dan penerapan } \\
\text { tentang gerak dalam } \\
\text { satu dimensi }\end{array}$ & $\begin{array}{l}\text { Gerak Satu } \\
\text { Dimensi }\end{array}$ & $\begin{array}{l}\text { 1. Perpindahan, } \\
\text { 2. Kecepatan, } \\
\text { 3. Percepatan, } \\
\text { 4. Diagram gerak, } \\
\text { 5. Percepatan konstan } \\
\text { dalam gerak satu } \\
\text { dimensi, dan } \\
\text { 6. Gerak jatuh bebas. }\end{array}$ & $\begin{array}{l}\text { 1. Diskusi, } \\
\text { 2. Tanya } \\
\text { jawab } \\
\text { 3. } \\
\text { Pemeca } \\
\text { han Soal } \\
\text { Konteks } \\
\text { tual } \\
\text { 4. Tugas }\end{array}$ \\
\hline 3 & $\begin{array}{l}\text { Mahasiswa mampu } \\
\text { menjelaskan konsep } \\
\text { vektor dan } \\
\text { penerapannya pada }\end{array}$ & $\begin{array}{l}\text { Gerak Dua } \\
\text { Dimensi }\end{array}$ & $\begin{array}{l}\text { 1. Vektor; } \\
\text { 2. Komponen Vektor; } \\
\text { 3. Perpindahan, } \\
\text { kecepatan, dan }\end{array}$ & $\begin{array}{l}\text { 1. } \\
\text { Diskus } \\
\text { i, } \\
\text { 2. Tanya }\end{array}$ \\
\hline
\end{tabular}

Gambar 7. Isi dari bagian Calendar 
PHYSICS I - LECTURE NOTES
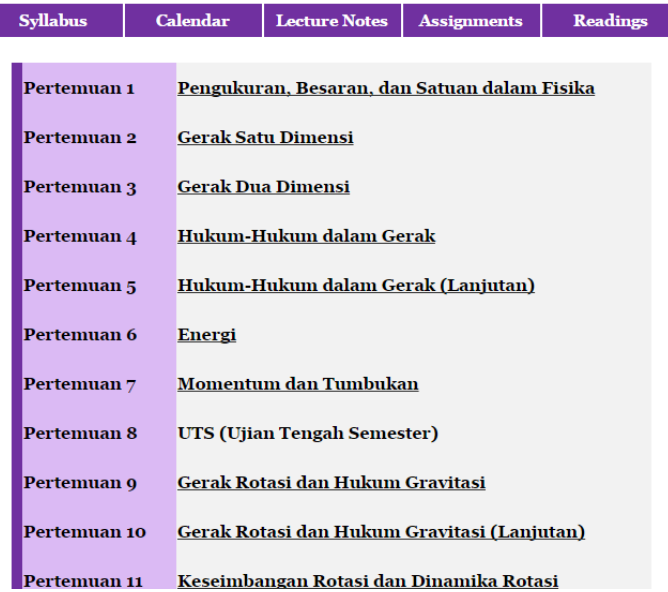

Gambar 8. Isi dari bagian Lecture Notes

PHYSICS I- ASSIGNMENTS

\section{\begin{tabular}{l|l|l|l|l} 
Syllabus & Calendar & Lecture Notes & Assignments & Reading \\
\hline
\end{tabular}}

A1 Serway, Raymond A dan Vuille, Chris. (2012). College Physics 9th Edition. Boston: Brooks/Cole.

A2 Abdullah, Mikrajuddin. (2016). Fisika Dasar I. Bandung: ITB.

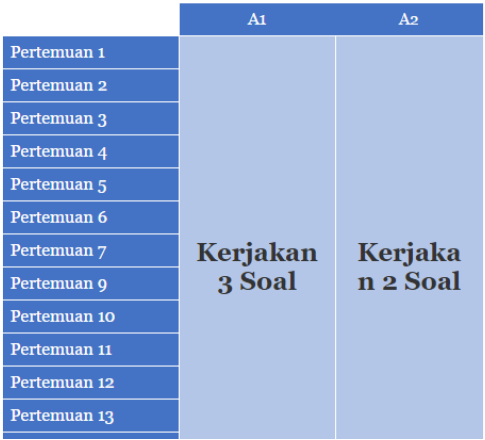

Gambar 9. Isi dari bagian Assignments.

PHYSICS I- READINGS

\section{\begin{tabular}{l|l|l|l|l} 
Syllabus & Calendar & Lecture Notes & Assignments & Readings
\end{tabular}}

A1 Serway, Raymond A dan Vuille, Chris. (2012). College Physics 9th Edition. Boston: Brooks/Cole.

A2 Abdullah, Mikrajuddin. (2016). Fisika Dasar I. Bandung: ITB.

\begin{tabular}{|c|c|c|}
\hline & A1 & $\mathrm{A}_{2}$ \\
\hline Pertemuan 1 & $\mathrm{~A} 1$ (Hal 1-18) & $\mathrm{A} 2$ (Hal 1-50) \\
\hline Pertemuan 2 & $\mathrm{~A} 1(\mathrm{Hal} 25-47)$ & $\mathrm{A}_{2}$ (Hal 81-140) \\
\hline Pertemuan 3 & $\mathrm{Al}_{1}\left(\mathrm{Hal}_{5} 6-75\right.$ & $\mathrm{A}_{2}$ ( $\left.\mathrm{Hal} 159-201\right)$ \\
\hline Pertemuan 4 & $\mathrm{~A}_{1}$ (Hal 86-112) & $\mathrm{A}_{2}\left(\mathrm{Hal}_{233-327)}\right.$ \\
\hline Pertemuan 5 & $\mathrm{~A}_{1}$ (Hal 86-112) & $\mathrm{A}_{2}$ ( $\mathrm{Hal}_{233-327)}$ \\
\hline Pertemuan 6 & $\mathrm{Al}_{1}$ (Hal 124-154) & $\mathrm{A}_{2}$ ( $\mathrm{Hal}_{345-416)}$ \\
\hline Pertemuan 7 & $\mathrm{~A}_{1}\left(\mathrm{Hal}{ }_{167-187)}\right.$ & $\mathrm{A}_{2}\left(\mathrm{Hal}_{435-487)}\right.$ \\
\hline Pertemuan 9 & $\mathrm{Al}_{1}(\mathrm{Hal} 198-221)$ & $\mathrm{A}_{2}\left(\mathrm{Hal}_{541-616)}\right.$ \\
\hline Pertemuan 10 & $\mathrm{Al}_{1}(\mathrm{Hal} 198-221)$ & $\mathrm{A}_{2}\left(\mathrm{Hal}_{541-616)}\right.$ \\
\hline Pertemuan 11 & A1 (Hal 235-257) & $\mathrm{A} 2$ ( $\mathrm{Hal} 629-677)$ \\
\hline Pertemuan 12 & $\mathrm{A1}$ ( $\mathrm{Hal}_{277-315)}$ & $\mathrm{A}_{2}\left(\mathrm{Hal}_{713}-8 \mathrm{o} 3\right)$ \\
\hline Pertemuan 13 & $\mathrm{A1}$ (Hal $331-354)$ & $\mathrm{A}_{2}$ (Hal 823-907) \\
\hline
\end{tabular}

Gambar 10. Isi dari bagian Readings 
Pada bagian Calendar (Gambar 7) terdapat keterangan tentang kegiatan perkuliahan tiap minggunya beserta Kompetensi dasar, Materi Pokok, Sub Materi, dan Strategi Perkuliahan. Pada bagian menu WEC Lecture Notes terdapat keterangan tentang materi yang diberikan tiap pertemuan beserta materinya dalam bentuk Google Slide Show (Gambar 8).

Pada bagian Assignments terdapat keterangan tentang tugas-tugas perkuliahan Fisika Dasar I tiap pertemuan yang harus dikerjakan oleh mahasiswa (Gambar 9). Pada bagian Readings terdapat keterangan tentang buku dan halaman buku yang sebaiknya di baca untuk menunjang perkuliahan berbasis WEC (Gambar10).

Develop (Tahap Pengembangan)

\section{Validasi Ahli Desain Instruksional}

Produk awal yang telah dikembangkan kemudian divalidasi oleh ahli desain instruksional yang hasilnya dapat dilihat pada Grafik 1. Hasil tersebut juga mengartikan bahwa WEC yang dikembangkan dapat digunakan tanpa revisi.

Pada aspek manajemen pembelajaran, WEC yang dikembang-kan mendapatkan nilai sebesar $91,67 \%$. sedangkan pada aspek pembelajaran kolaboratif mendapatkan nilai sempurna $100 \%$. Sehingga, kriteria validasi oleh ahli desain instruksional adalah "Sangat Baik" (Tabel 2).



Gambar 11. Hasil Validasi Ahli Desain Instruksional
Tabel 2. Hasil Validasi Ahli Desain Instruksional

\begin{tabular}{lccc}
\hline \multirow{2}{*}{ Kriteria Penilaian } & Skor & \multicolumn{2}{c}{$\begin{array}{c}\text { Aspek yang } \\
\text { Dinilai }\end{array}$} \\
\cline { 2 - 4 } & & 1 & 2 \\
\hline Sangat Baik & 5 & 10 & 20 \\
Baik & 4 & 4 & 0 \\
Cukup Baik & 3 & 0 & 0 \\
Kurang Baik & 2 & 0 & 0 \\
Sangat Kurang Baik & 1 & 0 & 0 \\
\hline \multicolumn{1}{c}{ Jumlah } & \multicolumn{2}{c}{14} & 20 \\
\%SS & & $93,33 \%$ & $100 \%$ \\
Rata-rata & \multicolumn{2}{c}{$96,66 \%$} \\
Kriteria & \multicolumn{3}{c}{ Sangat Baik }
\end{tabular}

Ket:

1 : Manajemen Pembelajaran $(\mathrm{Q}=3)$

2 : Dukungan Pemb. Kolaboratif $(\mathrm{Q}=4)$

\section{Validasi Ahli Media Pembelajaran}

Penilaian oleh ahli media pembelajaran yang menilai aspek desain antarmuka dan ketersediaan informasi pada WEC disajikan pada Gambar 12.

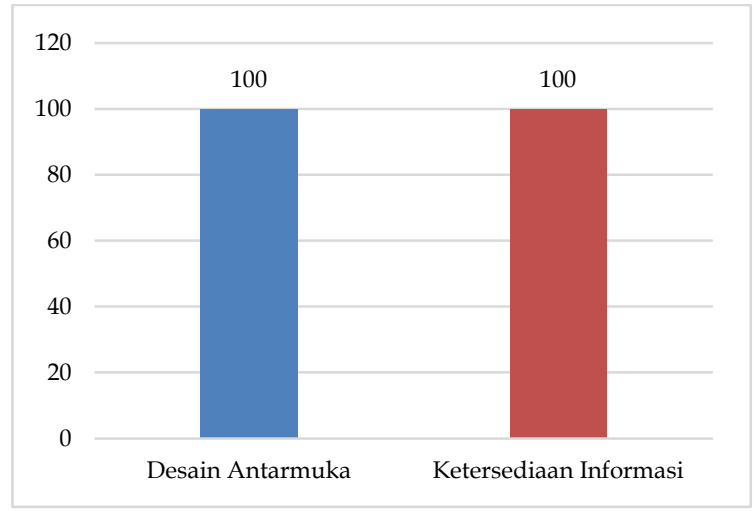

Gambar 12. Hasil Validasi Ahli Media Pembelajaran

Tabel 3. Hasil Validasi Ahli Media Pembelajaran

\begin{tabular}{lccc}
\hline \multirow{2}{*}{ Kriteria Penilaian } & Skor & \multicolumn{2}{c}{$\begin{array}{c}\text { Aspek yang } \\
\text { Dinilai }\end{array}$} \\
\cline { 2 - 4 } & & 1 & 2 \\
\hline Sangat Baik & 5 & 25 & 45 \\
Baik & 4 & 0 & 0 \\
Cukup Baik & 3 & 0 & 0 \\
Kurang Baik & 2 & 0 & 0 \\
Sangat Kurang Baik & 1 & 0 & 0 \\
\hline \multicolumn{1}{c}{ Jumlah } & \multicolumn{2}{c}{24} & 45 \\
\%SS & \multicolumn{2}{c}{$100 \%$ 100 \% } \\
Rata-rata & \multicolumn{3}{c}{ Sangat Baik } \\
Kriteria
\end{tabular}


Ket:

1: Desain Antarmuka $(\mathrm{Q}=5)$

2: Ketersediaan Informasi $(\mathrm{Q}=9)$

Aspek desain antarmuka WEC yang dikembangkan mendapatkan nilai 100\% dan ketersediaan informasi mendapatkan nilai $100 \%$. Sehingga, kriteria validasi oleh ahli media pembelajaran adalah "Sangat Baik" (Tabel 3).

\section{Validasi Ahli Website Designer}

Penilaian oleh ahli media pembelajaran yang menilai aspek desain antarmuka dan ketersediaan informasi pada WEC disajikan pada Gambar 13.

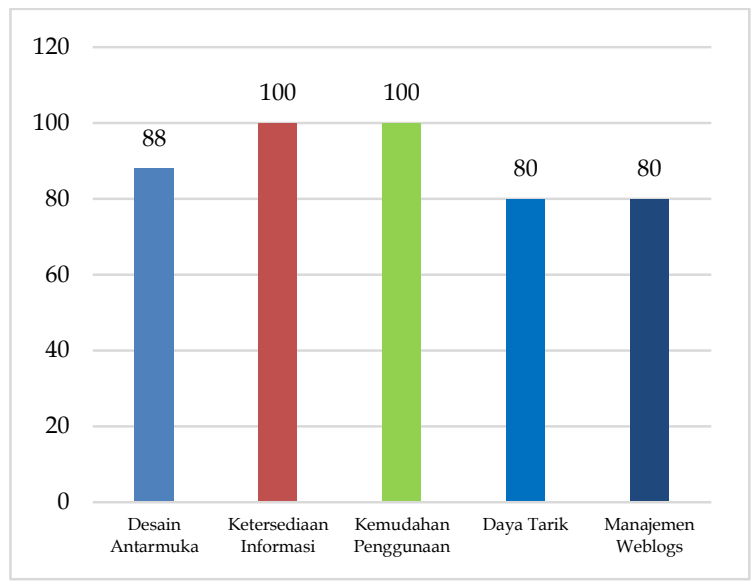

Gambar 13. Hasil Validasi Ahli Website Designer

Tabel 4. Hasil Validasi Ahli Website Designer

\begin{tabular}{|c|c|c|c|c|c|c|}
\hline \multirow[b]{2}{*}{ Kriteria Penilaian } & \multirow[b]{2}{*}{ Skor } & \multicolumn{5}{|c|}{ Aspek yang Dinilai } \\
\hline & & $\begin{array}{c}\text { Desain Antarmuka } \\
(\mathrm{Q}=5)\end{array}$ & $\begin{array}{c}\text { Ketersediaan } \\
\text { Informasi }(Q=9)\end{array}$ & $\begin{array}{c}\text { Kemudahan } \\
\text { Penggunaan }(\mathrm{Q}=5)\end{array}$ & $\begin{array}{c}\text { Daya Tarik } \\
(\mathrm{Q}=4)\end{array}$ & $\begin{array}{l}\text { Manajemen } \\
\text { Web }(Q=3)\end{array}$ \\
\hline Sangat Baik & 5 & 10 & 45 & 25 & 10 & 0 \\
\hline Baik & 4 & 12 & 0 & 0 & 10 & 12 \\
\hline Cukup Baik & 3 & 0 & 0 & 0 & 0 & 0 \\
\hline Kurang Baik & 2 & 0 & 0 & 0 & 0 & 0 \\
\hline Sangat Kurang Baik & 1 & 0 & 0 & 0 & 0 & 0 \\
\hline Jumlah & & 22 & 45 & 25 & 20 & 12 \\
\hline$\%$ SS & & $88 \%$ & $100 \%$ & $100 \%$ & $80 \%$ & $80 \%$ \\
\hline Rata-rata & & & & $89,6 \%$ & & \\
\hline Kriteria & & & & Sangat Baik & & \\
\hline
\end{tabular}

Tabel 5. Hasil Tanggapan Mahasiswa Uji Coba Terbatas Produk Awal (N=15)

\begin{tabular}{lccc}
\hline \multirow{2}{*}{ Kriteria Penilaian } & \multirow{2}{*}{ Skor } & \multicolumn{2}{c}{ Aspek yang Dinilai } \\
\cline { 3 - 4 } & & Kemenarikan Desain & Kemudahan Penggunaan \\
\hline Sangat Baik & 5 & 55 & 55 \\
Baik & 4 & 16 & 16 \\
Cukup Baik & 3 & 0 & 0 \\
Kurang Baik & 2 & 0 & 0 \\
Sangat Kurang Baik & 1 & 0 & 0 \\
\hline \multicolumn{1}{c}{ Jumlah } & 71 & $94,66 \%$ \\
$\quad$ \%SS & $94,66 \%$ & $94,66 \%$ \\
Rata-rata & \multicolumn{3}{c}{ Sangat Baik } \\
\hline
\end{tabular}

Tabel 6. Hasil Tanggapan Mahasiswa Uji Coba Diperluas Produk Akhir (N=90)

\begin{tabular}{|c|c|c|c|}
\hline \multirow{2}{*}{ Kriteria Penilaian } & \multirow{2}{*}{ Skor } & \multicolumn{2}{|c|}{ Aspek yang Dinilai } \\
\hline & & Kemenarikan Desain & Kemudahan Penggunaan \\
\hline Sangat Baik & 5 & 450 & 450 \\
\hline Baik & 4 & 0 & 0 \\
\hline Cukup Baik & 3 & 0 & 0 \\
\hline Kurang Baik & 2 & 0 & 0 \\
\hline Sangat Kurang Baik & 1 & 0 & 0 \\
\hline Jumlah & & 450 & 90 \\
\hline$\%$ SS & & $100 \%$ & $100 \%$ \\
\hline Rata-rata & & \multirow{2}{*}{\multicolumn{2}{|c|}{$\begin{array}{c}100 \% \\
\text { Sangat Baik }\end{array}$}} \\
\hline Kriteria & & & \\
\hline
\end{tabular}


Hasil penilaian oleh ahli website designer memberikan nilai $90 \%$ pada aspek desain antarmuka, 100\% pada aspek kemudahan penggunaan, $87,5 \%$ pada aspek daya tarik, dan $90 \%$ pada aspek manajemen web-logs. Sehingga, kriteria penilaian oleh ahli website designer adalah "Sangat Baik" (Tabel 4).

\section{Uji Coba I (Terbatas)}

Data hasil tanggapan mahasiswa pada uji coba terbatas dapat dilihat pada Tabel 5.

\section{Uji Coba II (Diperluas)}

Data hasil tanggapan mahasiswa pada uji coba diperluas dapat dilihat pada Tabel 6.

\section{Disseminate (Tahap Diseminasi)}

Setelah tidak ada perbaikan dari tahap Pengembangan (develop), dilakukanlah tahap diseminasi atau pengemasan dan penyebaran dari WEC yang telah dikembangkan. Pengemasan dan penyebaran yang pada tahap akhir penelitian ini hanya sebatas menyebarkan alamat web dengan membuat stiker website yang ditempel di laptop, kendaraan, dan buku. Selain itu juga dilakukan penyebarluasan informasi produk kepada dosen dan mahasiswa Prodi Pendidikan Fisika UIN Raden Intan Lampung melalui jejaring sosial.

Ucapan Terima Kasih

Peneliti mengucapkan terima kasih kepada validator yang telah membantu peneliti dalam menyelesaikan artikel ini, Ibu Dr. Yuberti, M.Pd. selaku validator desain instruksional, Bapak Irwandani, M.Pd. selaku validator Media Pembelajaran, dan Bapak Lukmanul Hakim, S.I.Kom. sebagai ahli Website Desaigner, serta seluruh mahasiswa Prodi Pendidikan Fisika Semester Ganjil 2016/2017 kelas Fisika Dasar I.

\section{Simpulan}

Telah dikembangkan WEC yang memungkinkan terjadinya komunikasi interaktif antara dosen dan mahasiswa baik secara individu maupun kelompok, dan menjadi sebuah alternatif belajar secara online yang setelah divalidasi oleh ahli desain instruksional, ahli media pembelajaran, dan ahli website designer, didapatkan nilai dengan kriteria "sangat baik" pada WEC serta memperoleh nilai dengan kriteria "sangat baik" setelah dilakukan uji coba terbatas $(\mathrm{N}=15)$ dan uji coba diperluas $(\mathrm{N}=90)$ dalam hal kemenarikan desain dan kemudahan penggunaan produk awal dan produk akhir dari WEC yang dikembangkan.

\section{Saran}

Pengembangan WEC berikutnya, sebaiknya dilakukan juga pada mata kuliah lain, dengan memperhatikan aspek ketersediaan informasi pada web, mendukung manajemen perkuliahan, dan aspek dapat mendukung pembelajaran kolaboratif.

\section{Daftra Pustaka}

Alfath, S. N., Ellianawati, \& Sukisno, M. (2013). Pengembangan media blended learning berbasis web enhanced course pada mata kuliah fisika dasar 2 jurusan fisika Unnes. Unnes Physics Education Journal, 2(1), 1-6.

Asyhari, A., Irwandani, I., \& Saputra, H. C. (2016). Conceptual instruction worksheet based on phet: developing teaching materials for construct student concept in photoelectric effect. Jurnal Ilmiah Pendidikan Fisika AlBiruni, 5(2), 193-204.

Asyhari, A., \& Silvia, H. (2016). Pengembangan media pembelajaran berupa buletin dalam bentuk buku saku untuk pembelajaran IPA terpadu. Jurnal Ilmiah Pendidikan Fisika Al-Biruni, 5(1), 1-13.

Asyhari, A., Sunarno, W., \& Sarwanto. (2014). Pengembangan perangkat pembelajaran fisika inkuiri terbimbing terintegrasi pendidikan karakter. Jurnal Inkuiri, 3(1), 62-75. 
Asyhari, A., Wati, W., Irwandani, \& Syahidah, N. U. (2016). Pengembangan lembar kerja peserta didik IPA terpadu berbasis inkuiri terbimbing terintegrasi pendidikan karakter melalui four step teaching material development. In Seminar Nasional Pendidikan Fakultas Keguruan dan Ilmu Pendidikan hal Bandar Lampung Universitas Lampung (pp. 3758). Bandar Lampung: Universitas Lampung.

Asyhari, A., Windarti, \& Wati, W. (2016). Pengembangan modul fisika SMA berbasis strategi REACT (Relating, Experiencing, Appliying, Cooperating, Transferring) pokok bahasan gerak melingkar kelas X. In Mathematic, Science, \& Education National Conference (pp. 95-100). Bandar Lampung: Fakultas Tarbiyah dan Keguruan IAIN Raden Intan Lampung.

Candiasa, I. (2004). Pengembangan modul berbasis web. Jurnal Pendidikan Dan Pengajaran, 3(3), 1-9.

Irwandani. (2014). Model pembelajaran Just In Time Teaching (JITT) berbantuan website pada topik listrik arus bolak-balik untuk meningkatkan keterampilan berpikir kreatif siswa SMA. Jurnal Ilmiah Pendidikan Fisika Al-Biruni, 3(2), 35-56.

Ke, F., \& Alicia, F. C. (2013). Web-Based teaching and learning across culture and age. New York: Springer.

Keing, C., \& McNaught, C. (2005). Guidelines for Web-enhanced Student
Learning Environments. Hongkong Centre for Learning Enhancement And Research.

Liu, L., \& Johnson, D. L. (2004). Web-based resources and applications. Computers in the Schools Interdisciplinary Journal of Practice Theory and Applied Research, 131-147.

Sa'ud, U. S. (2009). Inovasi pendidikan. Bandung: Alfabeta.

Sheard, J., \& Markham, S. (2005). Webbased learning environments: developing a framework for evaluation. Assessment Evaluation in Higher Education, 30(4), 353-368.

Thiagarajan, S., Semmel, D. S., \& Semmel, M. I. (1974). Instructional development for training teachers of exceptional children. Bloomington: Indiana University.

Woo, K., Gosper, M., McNeill, M., Preston, G., Green, D., \& Phillips, R. (2008). Web-based lecture technologies: blurring the boundaries between faceto face and distance learning. ALTJ Research in Learning Technology, 16(2), 81-93.

Zirkle, C. (2003). Course web site enhances classroom. Kappa Delta Pi Record, 39(2), 91-93.

Zumbo, D. B., \& Chan, K. E. (2014). Validity and validation in social, behavioral, and health sciences. New York: Springer. 